\title{
Level of Participation of Community-Driven Development Approach Beneficiaries of World Bank Assisted Projects in South Western Nigeria
}

\author{
Adeyemo, P. A. Oladosu, I. O., Kayode, A. O. and Orimafo, P. K. \\ Department of Agricultural Extension and Rural Development, Ladoke Akintola University of Technology, $P$. \\ M. B 4000, Ogbomoso, Oyo-State, Nigeria
}

\begin{abstract}
This study, examined level of participation of community-driven development approach beneficiaries of World Bank assisted projects in south western Nigeria. Multistage sampling technique was adopted in the selection of two hundred and forty six participants each of Fadama and CSDP projects respectively making a pooled total of four hundred and ninety two (492) respondents for the study. Firstly, two States from the Southwest of Nigeria were purposively selected. These were Oyo and Osun states. Secondly, fifteen percent of Local government areas in each State were randomly selected. Finally, 25\% of membership of each of the selected community associations was chosen. This resulted to 246 respondents each in respect of Fadama and CSDP and a pooled figure of four hundred and ninety two respondents were chosen for the purpose of this study. Data collected were analyzed using descriptive statistics. Most (64\%) of the respondents had secondary education. The respondent are far from their community to their meeting place, and $63.8 \%$ do not own vehicle. Fadama participants, participation in choice of project site ranked top with the mean of 1.94 while CSDP participants, participation in sensitization for community project take off (1.72) ranked $1^{\text {st }}$. Farmers should be encouraged to participate sensitization and choice of projects, this will enhance the performance of such projects.
\end{abstract}

Keywords: Fund, project attendance, project participation and ownership of mobility.

\section{Introduction}

Poverty remains entrenched in the developing countries due to failure of institutional services to the rural and urban farming households (World Bank, 2000). This state of affairs prevails despite prolonged efforts by many governments to improve rural and urban services and development programs. It is important to find out how communities can be empowered to contribute to their own development and, in the process, improve infrastructure, governance, services, economic and social development - that is, ultimately, the broad range of activities for sustainable poverty reduction.

Countries and their development partners have been trying to involve communities in their own development since the end of World War II, when the first colonies gained independence in South Asia (IFAD, 2003). Pioneers in both India and Bangladesh (then a part of Pakistan) developed a clear vision- of how it would be done: Local development should be planned and managed by local citizens, their communities, and their local governments within a clearly defined decentralized framework that devolves real power and resources to local governments and communities.

Several programmes, activities and projects are being executed at various levels including rural communities across the country; yet there is a lack of knowledge about how these services are sustained (Lerner,1995). Funding providers and the professionals who receive their funds are obligated to work towards sustaining programmes. Series of reasons might have been attributed to the cause of such scenario. Amongst is whether such programmes originated from the benefiting community or not. If communities were not carried along in the identification and subsequent implementation of such services to a significant stage, the likelihood of failure is imminent (World Bank, 1996).

The objectives are to;

$>$ Examine the socio-economic characteristics of the Fadama and CSDP participants (respondents) in the study area.

$>$ Analyze the problems encountered by beneficiaries while participating in community group activities in the study area.

$>$ Determine the level of participation of beneficiaries in community group activities in the study area. 


\section{Methodology}

The study was carried out in selected states (Oyo and Osun) of Southwest, Nigeria. Southwest Nigeria lies between latitude $5^{0} \mathrm{~N}$ and $9^{0} \mathrm{~N}$ of the Equator and longitudes $2.5^{0}$ and $6^{0}$ east of the Greenwich Meridian. It is bounded by the Atlantic Ocean in the south, Kwara and Kogi States in the north, Anambra state in the eastern Nigeria and Republic of Benin in the west. The study area has a land area of about $114,271 \mathrm{~km}^{2}$ representing about 12 percent of the country's total land area. The nation's population is put at about 140,003,542 with about 65 percent of this population living in the rural areas (National Population Commission (NPC), 2006). The Southwest zone comprises six states namely: Lagos, Ogun, Osun, Oyo, Ondo, and Ekiti States (Shahib et al., 1997). These states are situated mainly in the tropical rain forest zone with swamp forest in the coastal regions of Lagos, Delta, Ogun and Ondo states. The zone also covers the derived savannah in the extreme north of this region including Oyo, Osun, Edo and Ekiti states. The climate in southwestern Nigeria is predominantly humid with rainfall from $1500 \mathrm{~mm}$ to $3000 \mathrm{~mm}$ per annum . The mean monthly temperature ranges from $18^{\circ} \mathrm{C}$ to $24^{\circ} \mathrm{C}$ during the rainy season and $20^{\circ} \mathrm{C}$ to $35^{\circ} \mathrm{C}$ during the dry season (Shahib et al, 1997).

The population of the study were beneficiaries of Fadama and CSDP projects in the selected states of southwestern Nigeria. Multistage sampling technique was adopted in the selection of two hundred and forty six participants each of Fadama and CSDP projects respectively making a pooled total of four hundred and ninety two (492) respondents for the study. Firstly, two States from the Southwest of Nigeria were purposively selected. These were Oyo and Osun states. They were selected because of their participation in the two projects in southwest Nigeria. Secondly, fifteen percent of Local government areas in each state were randomly selected, making five Local Government Areas from each state and ten Local Government Areas altogether. In the third stage, 50\% each of total Fadama Community Associations and Community Development Associations (for CSDP participants) were chosen from the number of community associations participating in the two projects within the selected Local Government Areas. Finally, 25\% of membership of each of the selected community associations was chosen. This resulted to 246 respondents each in respect of Fadama and CSDP and a pooled figure of four hundred and ninety two respondents for the purpose of this study. following.

The tools and procedure that were employed elucidated the objectives of the study: this includes the

\section{Descriptive statistics:}

They are the mean, percentages and frequency distribution. These were used as tools to describe the socioeconomic, problems encountered by beneficiaries while participating in community group activities and the level of participation of beneficiaries in community group activities.

\section{Test of hypothesis:}

$\mathrm{H}_{01}$ : There is no significant relationship between selected personal characteristics of both Fadama and CSDP participants and their level of participation in community group activities.

Ordered Logistic Regression:

Ordered logistic regression was used for the test of hypothesis.

The logit model is:

$$
\begin{aligned}
& \operatorname{Pr}\left(Y=1 \mid X 1, X 2, \ldots X_{k}\right)=F\left(\beta_{0}+\beta_{1} X 1+\beta_{2} X 2+\ldots+\beta_{K} X_{K}\right) \\
& \operatorname{Pr}\left(Y=1 \mid X 1, X 2, \ldots X_{k}\right)=\frac{1}{1+e^{-\left(\beta_{0}+\beta_{1} X 1+\beta_{2} X 2+\ldots+\beta_{K} X_{K}\right)}} \\
& \operatorname{Pr}\left(Y=1 \mid X 1, X 2, \ldots X_{k}\right)=\frac{1}{1+\left(\frac{1}{e^{\left(\beta_{0}+\beta_{1} X 1+\beta_{2} X 2+\ldots+\beta_{K} X_{K}\right)}}\right)}
\end{aligned}
$$

Where;

$\mathrm{X}_{1}=$ age of respondents ;

$\mathrm{x}_{2}=$ household size;

$\mathrm{x}_{3}=$ years of formal education;

$\mathrm{x}_{4}=$ distance to community meeting place ;

$\mathrm{x}_{5}=$ income of respondents;

$\mathrm{X}_{6}=$ nature of project design;

$\mathrm{x}_{7}=$ gender consideration;

$\mathrm{x}_{8}=$ funding provided by respondents;

$\mathrm{x}_{9}=$ Bottom-top approach;

$\mathrm{x}_{10}=$ accountability of respondents' leaders;

$\mathrm{x}_{11}=$ types of benefits derived;

$\mathrm{x}_{12}=$ democratic choice of leadership; 
$\mathrm{x}_{13}=$ integrity of respondents' field officers;

$\mathrm{x}_{14}=$ support provided by respondents' Local Government

Logit and probit models are basically the same, the difference is in the distribution.

Logit - Cumulative standard logistic distribution $(F)$

Probit - Cumulative standard normal distribution $(\Phi)$

Both models provide similar results.

\section{Results And Discussion}

Results in Table 1 shows that $20.3 \%$ and $18.7 \%$ of Fadama and CSDP participants respectively had no formal education. However, $64.0 \%$ of pooled respondents had at least secondary education. $19.5 \%$ of the pooled respondents were not educated at all while about four-fifth had a taste of education. This result suggests that efforts of government seem to be paying off education wise. It further confirms the study of Richard (2003) that education is essential at all levels of economic activities as the better educated farmers tend to be innovators and acceptors of greater risks on trying new practices as against the poorly educated. The findings of Ahmed (2004) is also being corroborated that the gradual influence of education is significantly changing perception of farmers from primitive ideas and tradition as well as reluctance to innovations.

Results in Table 1 reveals that most of the respondents live in locations of almost 3.2 kilometers to their respective community meeting places. The mean distance to community meeting places for Fadama and CSDP respondents were $4.4 \mathrm{~km}$ and $1.9 \mathrm{~km}$ respectively . No CSDP participant however live in locations with a distance of more than $4 \mathrm{kms}$ to their meeting places. This indicate that Fadama respondents live far from their meeting places compared to CSDP respondents . Distance has a bigger challenge to contend with, such as poor transport system and bad road linkage. Both the field officers as well as participants will share from the challenges. However, about one-fifth of the pooled respondents live in locations less than $1 \mathrm{~km}$ to their respective community meeting points. The tendency for regular attendance of community meetings may be determined by how distant the meeting point is to their dwelling places. This situation also confirms that this study was carried out in a typical rural community that is well dispersed.

About $36.2 \%$ of pooled respondents own one means of mobility or the other while $63.8 \%$ claimed not owing any as contained in Table 1 . This implies that the possibility of the challenge of longer distance from their respective houses to their community meeting points might be solved by respondents who possess means of mobility.

Table 1: Socio-Economic Characteristics Of Respondents

\begin{tabular}{|c|c|c|c|c|c|c|}
\hline \multirow[b]{2}{*}{$\begin{array}{l}\text { Socio } \\
\text { Economic/Personal } \\
\text { Characteristics }\end{array}$} & \multicolumn{2}{|l|}{ FADAMA } & \multicolumn{2}{|l|}{ CSDP } & \multicolumn{2}{|c|}{ POOLED PARTICIPANTS } \\
\hline & Frequency & Percentage & Frequency & Percentage & Frequency & Percentage \\
\hline \multicolumn{7}{|c|}{$\begin{array}{l}\text { Years of formal } \\
\text { education }\end{array}$} \\
\hline Not educated at all & 50 & 20.3 & 46 & 18.7 & 96 & 19.5 \\
\hline $1-6$ & 37 & 15.0 & 41 & 16.7 & 78 & 15.9 \\
\hline $7-9$ & 45 & 18.3 & 44 & 17.9 & 89 & 18.1 \\
\hline $10-12$ & 62 & 25.2 & 28 & 11.4 & 90 & 18.3 \\
\hline 13 and above & 52 & 21.1 & 87 & 35.4 & 139 & 28.3 \\
\hline Mean $=8.5$ & & & & 9.0 & & \\
\hline \multicolumn{7}{|c|}{$\begin{array}{l}\text { Distance from house to } \\
\text { community meeting } \\
\text { place }(\mathbf{k m})\end{array}$} \\
\hline Less than 1 & 63 & 25.6 & 19 & 7.7 & 82 & 16.7 \\
\hline $1-2$ & 27 & 11.0 & 113 & 45.9 & 140 & 28.5 \\
\hline $2-3$ & 55 & 22.4 & 63 & 25.6 & 118 & 24.0 \\
\hline $3-4$ & 58 & 23.5 & 51 & 20.7 & 109 & 22.2 \\
\hline 4 and above & 43 & 17.5 & 0 & 0.0 & 43 & 8.7 \\
\hline Mean $=4.4$ & & & & 1.9 & & \\
\hline \multicolumn{7}{|c|}{ Ownership of mobility } \\
\hline Yes & 124 & 50.4 & 54 & 22.0 & 178 & 36.2 \\
\hline No & 122 & 49.6 & 192 & 78.0 & 314 & 63.8 \\
\hline
\end{tabular}

Field survey, 2013.

The first four constraints as shown in table 2 are interrelated. They revolve around chains of sequential activities (PIM, 2004). NFDO (2007) stated that community members have to be mobilized and sensitized, groups have to be formed and legally registered, group officers have to be elected and bank account have to be opened if not already in place. Additionally, Participatory Rural Appraisal have to be conducted for need assessment, Local Development Plans have to be drawn, submitted and approved . Counterpart fund of at least 
$10 \%$ also have to be paid before possible disbursement of funds for project implementation (PIM, 2004). These listed conditions requires significant time. Surely, respondents under this study were right in the stated challenges (Adeyemo, 2010). It also agrees with the findings of Adeyemo (2010) that skills of community group members must be built and properly enhanced to carry out participatory planning as well as to implement, operate and maintain sub projects even from project inception. Community groups must be built to overcome constraints and challenges . The challenge of location of meeting places (wms $=1.18$ ) which ranked $5^{\text {th }}$ confirms the dispersed nature of communities under this study. It should be recalled that the mean distance from respondents' houses to community meeting point was $3.2 \mathrm{kms}$. This is a major constraint. Community group meetings is compulsory under World Bank assisted projects such as Fadama and CSDP (NFDO, 2005). No meeting, no dues and remote chances of paying counterpart fund (wms $=0.99$ ). OYSFADO (2007) findings confirms that Fadama is pro poor in outlook. Even, the fact that many of the respondents belonged to cooperative societies did not make it comfortable for them to take loans in their various cooperative societies for the purpose of undertaking this obligation and payback in good time. This probably informed the inclusion of in kind contribution as an alternative to financial contribution as envisaged by project handlers to reduce the burden of cash payment (LEEMP, 2008). Possibility of elite capture $(\mathrm{wms}=0.49)$ ranked $7^{\text {th }}$. This might not have been a serious problem under this study but fewer respondents complained of some communities consisting of individual who acted as threat to hijack community project. Most of this elites capitalize on the perceived weaknesses of some community members to pay certain fees and thereafter act as lords over them (NFDO, 2007). The challenge which ranked least was gender insensitivity(wms=0.10). Definitely, Fadama and LEEMP are gender sensitive (World Bank, 2000). Emphasis on 25\% women participation was adhered to in conformity with our result on gender distribution of respondents in this study as in table 1 .

Table 2: Rank Order Distribution Of Fadama, Csdp And Pooled Respondents According To Constraints To Participation In Community Group Activities

\begin{tabular}{|c|c|c|c|c|c|c|c|}
\hline \multirow[b]{2}{*}{$\begin{array}{lr}\text { Constraints } & \text { to } \\
\text { participation } & \text { in } \\
\text { community } & \text { group } \\
\text { activities } & \end{array}$} & \multicolumn{2}{|l|}{ FADAMA } & \multicolumn{2}{|l|}{ CSDP } & \multicolumn{3}{|c|}{ Pooled participants } \\
\hline & $\begin{array}{c}\text { Weighted mean } \\
\text { score (WMS) }\end{array}$ & Rank & $\begin{array}{c}\text { Weighted mean } \\
\text { score (WMS) }\end{array}$ & Rank & $\begin{array}{c}\text { Weighted } \\
\text { mean score } \\
(\mathrm{WMS})\end{array}$ & Rank & remark \\
\hline Complex protocol & 2.18 & 1 & 2.12 & 2 & 2.14 & 1 & Serious \\
\hline $\begin{array}{l}\text { Slow decision making } \\
\text { process }\end{array}$ & 2.17 & 2 & 2.11 & 3 & 2.13 & 2 & Serious \\
\hline Complex protocol & 2.00 & 3 & 2.09 & 4 & 2.05 & 4 & Serious \\
\hline Slow decision making & 2.00 & 3 & 2.13 & 1 & 2.06 & 3 & Serious \\
\hline process & 1.24 & 4 & 1.12 & 5 & 1.18 & 5 & Not Serious \\
\hline $\begin{array}{l}\text { Location of meeting } \\
\text { point }\end{array}$ & 1.03 & 5 & 0.90 & 6 & 0.99 & 6 & Not Serious \\
\hline Payment of counterpart & 0.41 & 6 & 0.56 & 7 & 0.49 & 7 & Not serious \\
\hline fund & 0.39 & 7 & 0.48 & 8 & 0.43 & 8 & Not serious \\
\hline $\begin{array}{l}\text { Possibility of elite } \\
\text { capture } \\
\text { Dishonesty of group } \\
\text { officers } \\
\text { Gender insensitivity }\end{array}$ & 0.09 & 8 & 0.01 & 9 & 0.10 & 9 & Not serious \\
\hline
\end{tabular}

Source : Field Survey, 2013.

Cut off mean of constraints against Fadama and CSDP participants $=1.5$

The result in Table 3 shows the rank order distribution of respondents by their participation in each of the two projects and also when pooled together. Respondents participated in thirteen community group activities otherwise called participation elements. For Fadama participants, participation in choice of project site ranked top with the mean of 1.94 followed by participation in sensitization for project take off (1.69) and attendance of community meetings (1.69). Others were participation in payment of group dues (1.64) which ranked 4th, participation in payment of counterpart fund (1.59) ranked $5^{\text {th }}$ while participation in Participatory Rural Appraisal (1.54) ranked 6th. The least ranked were participation in programme planning and design (1.29) , participation in project maintenance (1.26) and participation in project appraisal (1.08) . For CSDP participants, participation in sensitization for community project take off(1.72) ranked $1^{\text {st }}$, participation in attendance of community meetings (1.69) ranked $2^{\text {nd }}$ while participation in choice of project site (1.68) ranked $3^{\text {rd }}$. The least ranked were participation in choice of service providers $(1.33)$ which ranked $11^{\text {th }}$, participation in project maintenance (1.29) which ranked $12^{\text {th }}$ and participation in project appraisal (1.10) which ranked $13^{\text {th }}$.

The mean score of Fadama participants was 1.35 while that of CSDP participants was 1.49. The pooled mean score was 1.42. All participation elements above the pooled mean were considered to be the dominant elements. From table 4.4, the first seven participation elements namely participation in choice of project sites, sensitization for project take off, attendance of group meetings, payment of group dues, payment of 
counterpart fund, Participatory Rural Appraisal and election of group officers were the dominant participation elements. This finding implies that the preconditions set for deriving any benefit from the World Bank assisted projects under consideration were well satisfied. These activities were strictly followed to achieve participatory activities. NFDO (2007) stated that community groups aiming to benefit from listed projects must be cooperative, united, democratic, and willing to participate freely without anyone coercing them. Qualification for project implementation is preconditioned by satisfactory participation in group activities without which nothing whatsoever could be benefitted (OYSFADO, 2007). The two activities in the appraisal stage ranked $12^{\text {th }}$ and $13^{\mathrm{th}}$. It might be as a result of the little importance attached to post project implementation activities.

Table 3: Rank Order Distribution of The Frequency Of Fadama, Csdp And Pooled Participants According To Participation Elements

\begin{tabular}{|c|c|c|c|c|c|c|}
\hline \multirow{2}{*}{ Participation indicators } & \multicolumn{2}{|l|}{ Fadama } & \multicolumn{2}{|c|}{ CSDP } & \multicolumn{2}{|c|}{ Pooled } \\
\hline & $\begin{array}{l}\text { Weighted mean } \\
\text { score }\end{array}$ & Rank & $\begin{array}{l}\text { Weighted } \\
\text { mean score }\end{array}$ & Rank & $\begin{array}{l}\text { Weighted } \\
\text { mean score }\end{array}$ & Rank \\
\hline Participation in choice of project site & 1.94 & 1 & 1.68 & 3 & 1.95 & 1 \\
\hline $\begin{array}{l}\text { Participation in sensitization for community } \\
\text { project take off }\end{array}$ & 1.69 & 2 & 1.72 & 1 & 1.71 & 2 \\
\hline Participation in payment of group dues & 1.64 & 4 & 1.67 & 4 & 1.66 & 4 \\
\hline Participation in payment of counterpart fund & 1.59 & 5 & 1.60 & 5 & 1.59 & 5 \\
\hline $\begin{array}{l}\text { Participation in Participatory Rural Appraisal } \\
\text { activity }\end{array}$ & 1.54 & 6 & 1.53 & 7 & 1.53 & 7 \\
\hline $\begin{array}{l}\text { Participation in election of community group } \\
\text { officers }\end{array}$ & 1.48 & 7 & 1.60 & 5 & 1.54 & 6 \\
\hline Participation in choice of service provider & 1.36 & 10 & 1.33 & 11 & 1.34 & 10 \\
\hline Participation in programme planning and design & 1.29 & 11 & 1.35 & 10 & 1.32 & 11 \\
\hline Participation in project maintenance & 1.26 & 12 & 1.29 & 12 & 1.28 & 12 \\
\hline Participation in project appraisal & 1.08 & 13 & 1.10 & 13 & 1.09 & 13 \\
\hline
\end{tabular}

Source : Field survey, 2013

Fadama mean $=1.35$, CSDP mean $=1.49$, pooled mean $=1.42$

The result in Table 4 shows that fadama and CSDP participants in this study were almost evenly spread across the three participation categories. $29.3 \%$ and $36.7 \%$ of Fadama and CSDP participants respectively fell to the low participation category . 26.8\% Fadama and 40.3\% CSDP participants were in the medium participation category while in the high participation category were $43.9 \%$ and $23.0 \%$ of Fadama and CSDP participants respectively. The mean participation score for Fadama and CSDP participants were 1.35 and 1.49 respectively while standard deviation were 0.26 and 0.32 respectively.

This finding implies that more participants were categorized into lower participation level in CSDP more than Fadama while more CSDP participants were categorized into moderate participation more than Fadama. However, almost twice the number of CSDP participants categorized into high participation level fell into the same category in the Fadama project. Simply, fadama project attracted more participants in terms of high participation probably because of the economic benefits which in some cases were personal to respective beneficiaries unlike social facilities that could be benefitted in CSDP project. Key findings according to Trond (2001) suggested that beneficiary participation was usually successful in projects using participatory designs. Participatory work improved significantly, showing a shift from isolated concerns to a broader operational frameworks for participation in community project implementation. Wenger Trayner (2011) also stated that communities of practice usually involve multiple levels of participation because involvement can produce learning in multiple ways and the boundaries of a community of practice are more flexible than those of organizational units or teams. These typical categories of membership and participation include:

- Core group: a relatively small group of people whose passion and engagement energize and nurture the community.

- $\quad$ Active participants: members who are recognized as practitioners and define the community (though they may not be of one mind as to what the community is about).

- Occasional participants: members who only participate when the topic is of special interest, when they have some specific issues to contribute, or when they are involved in a project related to the domain of the community. 
- $\quad$ Peripheral participants: people who have a sustained connection to the community, but with less engagement and authority, either because they are still newcomers or because they do not have as much personal commitment to the practice. These people may be active elsewhere and carry the learning to these places. They may experience the community as a network.

- Transactional participants: outsiders who interact with the community occasionally without being members themselves, to receive or provide a service or to gain access to artifacts produced by the community, such as its publications, its website, or its tools.

A close look at the participation activities show that they could be grouped into three stages namely preparation, implementation and appraisal (NFDO, 2005). Summarily according to Oladosu et al. (2005), this result implies that participants were fairly distributed around the three participation level categories with majority participants exhibiting improved participation in slated community group activities as shown in figure 1.

Table 4: Distribution of respondents according to their level of participation in community group activities

\begin{tabular}{|c|c|c|c|c|}
\hline \multirow[b]{2}{*}{ Participation level categories } & \multicolumn{2}{|c|}{ Fadama } & \multicolumn{2}{|c|}{ CSDP } \\
\hline & Frequency & Percentage & Frequency & Percentage \\
\hline Below $\bar{X}$ & 72 & 29.3 & 91 & 36.7 \\
\hline $\bar{X}$ to $\bar{X}+1$ S.D. & 66 & 26.8 & 100 & 40.3 \\
\hline High & 108 & 43.9 & 57 & 23.0 \\
\hline $\begin{array}{l}\text { Above } X+1 \text { S.D. } \\
\text { TOTAL }\end{array}$ & 246 & 100.0 & 246 & 100.0 \\
\hline
\end{tabular}

Source : Field survey, 2013

Mean participation score for Fadama $=1.35$, S.D. $=0.26$

Mean participation score for CSDP $=1.49$, S.D. $=0.32$

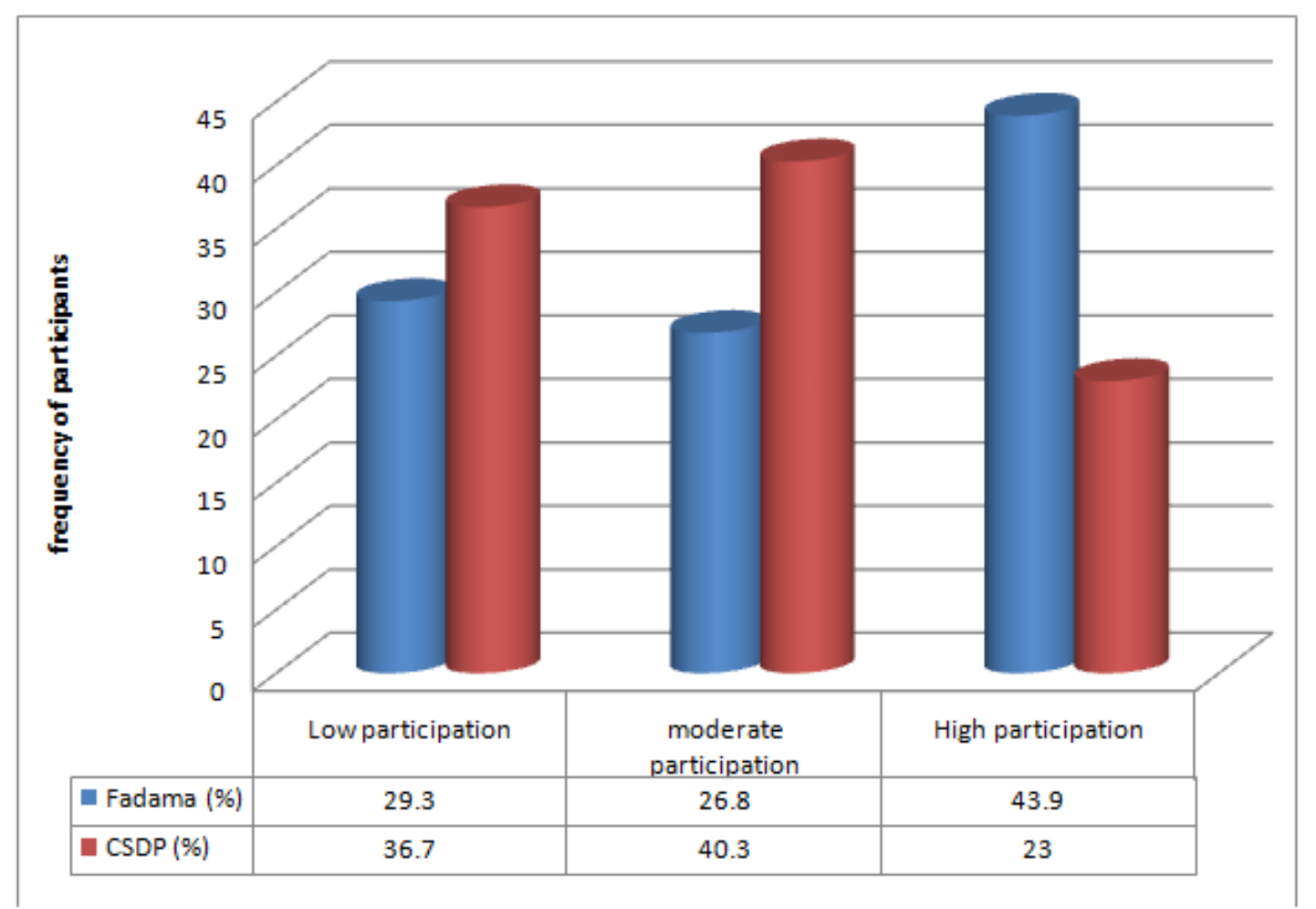

Figure 1: Bar chart showing categorization of Fadama and CSDP participants according to their level of participation in community group activities 
Test of hypothesis:

- The result of Pearson Product Moment Correction (r) of Fadama participants shows that significant relationship exist between participation level of respondents and household size $\quad(\mathrm{r}=0.330 ;<\mathrm{P}=0.01)$; years of formal education $(\mathrm{r}=0.218 ; \mathrm{P}<0.01)$; income $(\mathrm{r}=0.060 ; \mathrm{P}<0.01)$ and age $(\mathrm{r}=-0.031 ; \mathrm{P}<0.01)$.

- Pearson correlation of CSDP participants shows that significant relationship exist between participation level and household size $(\mathrm{r}=0.119 ;<\mathrm{P}=0.10)$, years of formal education $\quad(\mathrm{r}=0.162 ; \mathrm{P}<$ $0.01)$; income $(\mathrm{r}=0.194 ; \mathrm{P}<0.01)$; age $(\mathrm{r}=-0.132 ; \mathrm{P}<0.01)$ and distance from respective houses to community meeting places $(r=-0.458 ; \mathrm{P}<0.01)$.

- Generally, in the two projects (Fadama and CSDP) age, household size, years of formal education and income are related to participation level of participants.

- $\quad$ Distance from respective houses to community meeting places was only related to CSDP project in terms of participation level of respondents.

Table 5: Summary Of Pearson Correlation Analysis Of Participants Showing Relationship Between Selected Personal Characteristics And Level Of Participation In Community Group Activities

\begin{tabular}{|c|c|c|c|c|c|c|}
\hline \multirow{2}{*}{$\begin{array}{l}\text { Selected Personal characteristics of } \\
\text { participants }\end{array}$} & \multicolumn{3}{|c|}{ Fadama participants } & \multicolumn{3}{|c|}{ CSDP participants } \\
\hline & r-value & p-value & remark & r-value & p-value & remark \\
\hline Age & $-0.031 *$ & 0.006 & $\mathrm{~S}$ & $-0.132 * *$ & 0.039 & $\mathrm{~S}$ \\
\hline Household size & $0.330 *$ & 0.000 & $S$ & $0.119 * * *$ & 0.062 & $S$ \\
\hline Years of formal education & $0.218 *$ & 0.001 & S & $0.162 * *$ & 0.011 & S \\
\hline Distance from house to meeting places & -0.571 & 0.350 & NS & $-0.458 *$ & 0.000 & $\mathrm{~S}$ \\
\hline Income & $0.060 *$ & 0.000 & $\mathrm{~S}$ & $0.194 *$ & 0.002 & $S$ \\
\hline
\end{tabular}

Source Field survey, 2013

* Correlation is significant at the 0.01 level ( 2 tailed)

** Correlation is significant at the 0.05 level ( 2 tailed)

*** Correlation is significant at the 0.10 level ( 2 tailed)

\section{Conclusions And Recommendations}

Most (64\%) of the respondents had secondary education. Government and non-governmental organizations should encourage free adult educational programmes among farmers. The respondent are far from their community to their meeting place, and $63.8 \%$ do not own vehicle. Feeder roads should be rehabilitated and farmers meeting location should be closer to their individual communities. Fadama participants, participation in choice of project site ranked top with the mean of 1.94 while CSDP participants, participation in sensitization for community project take off (1.72) ranked $1^{\text {st }}$. Farmers should be encouraged to participate sensitization and choice of projects, this will enhance the performance of such projects. Fund was an important constraint to participation of community-driven development progrsmme.. Therefore, soft loans should be given to farmers.

\section{References}

[1]. P. A. Adeyemo, Analysis of farmers' Participation in the Second Fadama Development Project in Oyo State, Nigeria. Unpublished Msc thesis in the Department of Agricultural Extension and Rural Development, LAUTECH, Ogbomoso, 2010.

[2]. S. Ahmed, T \& D system-search for greater farmers' participation. Paper presented at the technical meeting, Sept 1989, Bauchi, 2004.

[3]. IFAD, Decision Tools for Rural Finance. Rome, 2003.

[4]. LEEMP, Project Implementation Manual, 2008.

[5]. R. Lerner, America's Youth in crisis. Thousand Oaks, CA: Sage publications, 1995.

[6]. National Population Commission (NPC), Fact sheet for Nigeria Population. Retrieved from URL: www/ npc.org/ population htm, 2006.

[7]. NFDO (National Fadama Development Office), Poverty reduction through increased productivity and empowerment NFDO/Project Coordination Unit, Abuja, Nigeria, 2005.

[8]. NFDO (National Fadama Development Office), Poverty reduction through increased productivity and empowerment. NFDO/Project Coordination Unit, Abuja, Nigeria, 2007.

[9]. I. O. Oladosu, J. A. Oladejo, and T. N. Akinniran, Evaluation of Womens' Access to Production Resources in Ede Zone of Osun State, Nigeria: Implications for Gender- $\quad$ Relevant Trainning. Annals of Agricultural Sciences, 3(2): 75-83, 2004.

[10]. OYSFADO, Beneficiary impact assessment of Fadama II Project in Oyo State, 2007.

[11]. PIM, (2004): Project Implementation Manual of Fadama II Project, 2004.

[12]. I. O. Richard, Administration and programme planning in Extension by ABIC Publishers Enugu and Lagos, Nigeria Pp 23-24, 2003.

[13]. B. A. Shaib, A. Adamu, and J. S. Baksli, Nigeria: National Agricultural Research Strategy Plan (1996-2000). Department of Agricultural Sciences, Federal Ministry of Agriculture and Rural Development, Abuja, Nigeria, 335pp, 1997.

[14]. V. Trond, Participation in project preparation - lessons from World Bank-assisted projects in India". Volume 1, 2001.

[15]. World Bank, June, PID Report No.PIC3995 - Sierra Leone-Recovery and Reintegration Project 1999. June, Report No.19502, 1999.

[16]. World Bank, "Sourcebook on Community-Driven Development in the Africa Region: Community Action Programs", 2000. 